\title{
Political Reform in Iraq Between the Problems and the Elements of Strengthening: Intellectual Vision
}

\author{
Muna Hamdi Hikmat \\ University of Baghdad, Baghdad, Iraq
}

\begin{abstract}
Throughout its history, Iraq has experienced numerous situations of instability as a result of the military revolutions and coups that occurred at different periods of time. However, the Iraqi status after 2003 that accompanied by frequent economic, political, and administrative crises with the futility of reform calls from time to time, led to a result that the country survival, as a unified entity and state, is threatened. So, it is necessary to work on a comprehensive reform process in the structure of the Iraqi political system to improve the functioning of the government and parliament to the level of good governance based on the principle of justice and equal opportunities for all citizens to raise the society towards a better tomorrow, to suck up the popular discontent, and to avoid the occurrence of the revolution and the unknown result of chaos.
\end{abstract}

Keywords: political problems in Iraq, Iraq after 2003, Iraqi political system

Throughout the ages, societies have been trying to renew their lifestyles and reform their own realities.

The Iraqi reality witnessed a change in its political system after 2003 by the American military intervention, which brought the country a stage of chaos and political, security and administrative crises, and disasters that claimed the lives of thousands of innocent people.

As a result of the weakness that dominated the mechanism of the state institutions work, which caused popular discontent and resentment, then led to demonstrations included most of the provinces of Iraq demanding reform of the political and economic situation, as well as the reform of the security and judicial services in the state. These demonstrations ended with adopting several procedures by the government to deal with these demands, but the government did not achieve full responses to them.

As a result of the changes taking place and their significance and implications on the Iraqi issue, we proceed from the premise that political reform in Iraq is an urgent issue imposed by the necessities of the stage. There are mass demands calling for reform and political change.

At the same time, there is no political fertility to produce the desired reforms, but there is a futile debate about proposing ideas and initiatives that cannot be tamed and cannot be a means of producing realistic solutions.

This negativity brings us back to talk about obstacles of political reform in Iraq that is facing reform and even deflecting it from its route in some cases. But this does not prevent future opportunities and development for reform in order to avoid revolutions.

Corresponding author: Muna Hamdi Hikmat, Ph.D. in Political Sciences, lecturer, College of Political Sciences, University of Baghdad, Baghdad, Iraq; research field: political thought. 
To demonstrate the hypothesis of research, we will try to answer the following questions:

(1) What is meant by reform in general and political reform in particular?

(2) What is the historical context of the reform concept?

(3) Who qualifies for the reform process?

(4) What are the reasons for the need for political reform in the presence of a pluralistic democratic system? What are the reasons of reform?

(5) What are the obstacles to political reform?

(6) What are the mechanisms and reinforcements of political reform?

Based on this, the search has been divided into the following pivots:

(1) The first pivot: The concept of political reform and its historical origins;

(2) The second pivot: The most important issues and problems that affect the political reform in Iraq;

(3) The third pivot: The basic elements to strengthen the process of political reform in Iraq.

\section{The Concept of Political Reform and Its Historical Origins}

Since the creation of God, humankind and his majesty sends prophets, messengers, imams, and righteous people for the reform of human beings, their guidance to the path of right and righteousness, and the establishment of good governance.

Reform is indispensable and life would not last on earth without it. The intellectual aspect of the entire reform process is the most important aspect of the wheel of life.

Everyone is looking for the meaning of reform and then its goal, where reform exists and whether it has roots ingrained in ancient times. To find out all these questions, the answer was divided into two main points.

\section{The Concept of Political Reform}

The root of the word "reform" in Arabic language (Al-Islah is Uslih-Islahan) means "the elimination of corruption among the people," and reconciliation between them, which is the opposite of corruption (Al-Said, 2011).

Reform imposes itself on human relations and takes it from a situation to a better one, or shifts from something and leaves it to other thing (Al-Said, 2011).

The word "reform” was mentioned in the Qur'an in many Qur'anic texts in more than one sura.

In an Aya, God described Ibrahim (Peace be upon him), "We chose him in this world and in the Hereafter, he will be among the righteous". . About Jesus (Peace be upon him), "He will speak to the people from the crib, and in adulthood, and will be one of the righteous"”2. And about Shua'eb (Peace be upon him), "I desire nothing but reform, as far as I can”3. In dealing with the word reform, we find that it contains two basic pillars, on which reform is based, one of which is corruption, and the other is a human will to carry out reform (Alay, Yasin, \& Al-Ithawi, 2014).

The Oxford Dictionary defines "reform" as "change for the better in the case of imperfections, especially in corrupt or unfair political institutions” (Al-Said, 2011).

This definition essentially involves the idea of radical, comprehensive, and lasting change for the better in the political aspect to avoid the shortcomings or errors that arise in political practice without compromising the

\footnotetext{
${ }^{1}$ Holy Quran, Surat Al-Baqarah, verse 15.

2 Holy Quran, Surat All Umraan, verse 46.

${ }^{3}$ Holy Quran, Surat Hood, verse 88.
} 
essence of the political system, namely, an adjustment of political behavior. The Webster Dictionary for political terminology defines it as "improving the political system to eliminate corruption and tyranny" (Saad, 1983).

This means that the change in the practices and behaviors of corrupt and authoritarian political institutions is only a correction of the path of political life and its constitutional and legal form.

There are those who define reform in terms of distinguishing it from other concepts, such as the revolution. The Encyclopedia of Politics defined it as "non-fundamental modification or development in the in the form of governance or social relations without prejudice to its foundations (i.e., improvements in the existing regime to prevent the revolution) (Al-Kayali, 2009).

Thus, we can see that in the old Arabic dictionaries, there is no definition of reform other than "reform against corruption." While in the European dictionaries, we see that the word "reform" means giving another picture of something or recreating something to look new (Baalbaki, 1977).

It can be said that political reform is the essence of political democracy through its emphasis on public freedoms and releasing the talents of creativity and thought on the political side. Reform is parallel to progress and involves the idea of radical change that is comprehensive, sustainable, and cannot be undone, in order to achieve the objectives, changing gradually from current state to what is possible and to what should be, with ideas of renaissance, potential, and capabilities.

\section{Historical Assets of Political Reform Concept}

The concept of reform is not a modern concept, but an old concept that emerged with the first cases of corruption on the earth when Cain killed and then buried his brother Abel. Hence, the phenomenon of reform began as an antidote to the corrupt act that came by the hands of Adam's son (Alay, Yasin, \& Al-Ithawi, 2014).

History tells us that the call for reform was rooted in ancient Western thought. It was the ultimate goal of many philosophers, leaders, and political and social movements around the world. Plato called for the power of philosophers because they are the most knowledgeable and wise people to achieve justice and social equality (Badawi, 1942).

In the Roman era, there were reform efforts of a number of Roman philosophers, such as Cicero and Cinca, in their attempts to modify the warp of human rights by equating them in front of the law that was, at that time, accused of brutality (Powell, 1985).

In the modern era, the idea of reform was a major theme in the political theories of philosophers and thinkers from the days of Machiavelli until Karl Marx in the 20th century, In Mikavelli's famous book The Prince, he spoke of the importance of the reform that he embodied in his project to establish a strong state that would take on the responsibility of advancing Italy to overcome its weakness (Al-Taan, 1992).

As well as the American and French revolutions, which came to achieve reforms, political were in the first place, putting an end to political tyranny and secured the civil and political rights of citizens ${ }^{4}$.

The idea of technocracy was first used in 1919 by William Henry Smith that relied on governments to inject a group of educated elites, specialists, and scientists into the administration of the state as the most efficient to bring about reforms to their countries (Thomas, 1964).

\footnotetext{
${ }^{4}$ The Declaration of Independence of the United States in 1776 and the French Declaration on Human Rights and Citizen in 1789.
} 
For example, the main reason behind America's power as a great nation is its political system that based on the separation among the three authorities, mutual respect for each other, and the adoption of the Constitution in the application of laws.

In the Arab land, the Ottoman Empire carried out many reforms on the military side, followed by reforms in other political, social, and administrative aspects. But the reform efforts of the Ottoman Empire were slow, partial, and belated (Batato, 2005).

As for the Arab side in the Ottoman Empire, many reformist ideas have emerged from a number of Arab thinkers, such as Tahtawi in defending the modern state model, Muhammad Abdo in advocating to religious reform, as well as Afghani and Kawakibi in criticizing the political and religious tyranny.

These ideas represented the nucleus of Arab nationalist thought, on which the second generation of Arab nationalists built their ideas, such as Najib Azouri and Sateh Al-Husri, and others who contributed to the emergence of the Arab nationalist movement that led to the separation of the Arabs from the Ottoman Empire in the end of World War I (1-Hassani, 1993).

With most of the Arab countries under the control of European colonialism, efforts were being made to achieve the independence that achieved and the result of the subordination of all Arab states to authoritarian regimes that sought to maintain their control over power and the state without registering any initiative in reform (Al-Said, 2011).

The absence of freedom and justice in the Arab world under these authoritarian regimes has made extremist ideas to grow and paved the way for the emergence of terrorist movements, which led the West to put pressure on the governments of Arab countries to move towards reform, and responded to these external pressures through partial reforms to contain those pressures (Farouk \& Slogelt, 2003).

In Iraq, the ancient civilizations of Iraq, such as Sumerian and Babylonian civilizations, have known many reforms by their ancient kings of Iraq. Slabs of clay was found containing many reform writings and a black marble obelisk was found in Babylonian language in the cuneiform script of the most famous kings of Babylon, Hamorabi. He wrote his reforms, which were revealed in 282 legal articles, to deal with corruption, bribery, and other reforms in order to eliminate evil and fraud, and seek the good and welfare of the people (Al-Asadi, Sakhi, Lafta, \& Taamas, 2013).

\section{The Most Important Issues and Problems That Affect the Political Reform in Iraq}

In the political reform process in Iraq, all pens are turned towards the possibility of creating and building analytical intellectual visions to enhance the political process in it. Because of their direct and indirect influence in the political process, a number of issues and problems to be monitored and analyzed presents were presented, and therefore, their treatment of the prerequisites and conditions is essential to promote political reform. The most important of these issues and problems are as follows:

(1) The state does not reach the stage of contact with reality and the root of the consciousness to turn the reform into the characteristics of regularity in relations, discipline in responsibilities, and rationalization of options. Because the deterioration of the entity of the state to a stage less than that level will inevitably lead to the chaos of transactions and default in commitments (Hafez, 2001).

(2) The issue of citizenship as a basis for the relationship between the ruler and the citizens, especially as it involves the system of duties imposed on the citizen and the rights guaranteed to him, that been hidden in the face of sectarian and ethnic devotion (Hafez, 2001). 
(3) The weakness and fragility of civil society institutions in light of the multiplicity and diversity of government restrictions imposed on its organizations, represented by the political society's acquisition of the activities of civil society through the exclusion of its institutions. It contained its sincere activities in criticizing the wrong policies of the political community and correction the deviant positions, which does not make civil society to be an influential force in the process of political reform (Al-Zubaidi, 2011).

(4) Economic and social problems that have negative effects on reform if they continue. The problem of unemployment is at the forefront of these problems, which hampered progress and development in most societies, and face most of the world at different levels of progress and systems. This problem is concentrated in the youth, especially those who are educated, creating an environment conducive to the growth of phenomena of violence and crime (Al-Dabbagh, 2007).

This problem is the result of other problems-trampling the state efforts to diversify sources of income and the expanding of the non-oil economy production base, which reduced the ability of the state to provide jobs and paved the way for the migration of many young people abroad, escape from poverty, political injustice, and dictatorship (Al-Dabbagh, 2007).

Other economic problems were the decline in oil prices, the doubling of state expenditures, the scarcity of revenues, the inability to create sustainable economic, and monetary and productive alternatives, all of which led to external borrowing and to external indebtedness (Al-Dabbagh, 2007).

As well as the economic predicament witnessed by the economy after the looting and oppression that have occurred and still occur, it is an obstacle to political reform. Despite this, the deterioration of the economic conditions cannot be considered a justification for the absence of reform, justice, freedom, and equality (Hamid, 2014).

In addition to the above, the absence of awareness of the educational system in reality and its weakness in the performance of its role, as it still suffers a lot of organizational and professional problems, and this dilemma needs real reform (Dawn, 2000).

(5) Lack or weakness of transparency in the work of administrative bodies makes them unable to achieve the desired goals and this affects negatively on the political system as a whole. The application of transparency is an important issue to be observed in administrative practices and public administration organs in order to consolidate the rules of good governance (Al-Lozi, 2002).

(6) External pressures and their inputs negatively affect the performance of the political system of its institutional functions, especially curbing the sovereignty of the state, reducing the influence of the government, weakening the prestige of the law, and reducing the unleashed forces of evil, chaos, and sabotage. In order to refer society to the arena to settle the racial, sectarian, and tribal calculations, the impossibility of reaching the reform boat and failure to establish projects of renaissance and development are the results (Faris, 2017).

(7) The lack of a positive environment to establish genuine national reconciliation away from self-interest. As well as the absence of a culture of recognition of error, forgiveness, apology, tolerance, credibility, and inflexibility in dealing with the disputed issues where each bloc adheres to its opinion without taking into account the opinion of the other side (Al-Zubaidi, 2011).

(8) They stir the sectarianism and tribal strife, especially from some losing parties that want to compensate for their loss in blocking the reform efforts under the slogan of rejecting half-solutions. It does not realize that half-solutions are better than non-existence, nor does it believe in gradual political peace. It rejects modernization, reform, and change (Al-Jaadi, 2011). 
(9) The independence of the judiciary is not fully independent, under all those who stand in front of the unified political vision being held accountable and accountability of all those involved in the violence. If the judiciary does not play the role of an accountant for every drop of blood, it would naturally affect on the political process and the expected political reform (Issawi, 2015).

(10) The existence of models in the pyramid of power that controls with an old mentality has a military capacity rather than political, controlling with "commands method", where the existence of such models in government is contrary to political reform (Al-Jaadi, 2011).

\section{The Basic Elements to Strengthen the Process of Political Reform in Iraq}

The reform processes in modern countries have the characteristic of continuity, flexibility, specialization, rationality, the realism of the goals, their truth, and integrity, and not individual personal judgments.

The reform process cannot be achieved unless a set of conditions and elements are available in the context of positive significance before starting the reform process. The most important are following:

(1) Any movement toward political reform must start from three levels: the individual, the society, and the authority. The reform of the individual is the goal of reform through the process of family and school education, to create the social upbringing that is reliable for human building in a way that making him a productive individual, seeking for institutional construction at all levels.

If this is achieved, we will be able to produce and create a moral society that is the basis and the starting point for reform in the in a broad or comprehensive sense.

In order to get an integrative reform process, the political authority must seek to achieve reform, which must be consistent with the demands of the people and is the source of the legitimacy of political authority.

(2) Diagnosing the country's crisis (i.e., identifying the source of the country's deficit, imbalances, and shortcomings).

(3) The need for institutions interests with thinking and strategic planning to provide advice and opinion to decision-makers to ensure disciplined behavior in the face of conflict-related situations and crises, and that are a challenge to the work of state institutions.

(4) To strengthen the bonds of national integration in the community structure, which will consolidate the foundations of national unity.

(5) Popular participation in the preparation of reform programs, to assure the people that their voice is heard and respected.

\section{Possible Solutions to Achieve Political Reform in Iraq}

The strength and success of the process of political reform in Iraq is avoiding its antagonists, the most important of which is the uncontrolled revolution that leads only to chaos and incalculable results.

So, there are a range of possible solutions that can put reform work on track and bring it to better results in the future:

(1) The recognition of the legitimacy of the ruling regime by the forces calling for reform must be predominantly peaceful claim. This is an encouraging factor in pushing the regime towards further reform steps because this dispels concerns about these forces as potential alternatives and encourages them to be treated as national forces seeking greater participation within the existing system (Atwan, 2011).

(2) Completing the institution-building process, institutionalizing the work of the state, asserting its independence from the ruler's person, and modernizing its apparatuses. 
This reinforces its role in the implementation of public policies and in facing social and economic problems which the society suffers from (Mahfouz, 2005).

(3) Working on devoting the principle of citizenship as one of the main requirements for the promotion of the process of political reform, it should guarantee by this principle of the citizen rights and the duties imposed on him. This principle implies the assertion of the law rule by applying it to all without discrimination for one reason or another. Moreover, the principle of citizenship establishes the meaning of a higher loyalty of the state than any other loyalties (Mahfouz, 2005).

(4) Taking serious steps to establish a democratic political culture and disseminate it in society that contributes to the promotion of democratization and the consolidation of democratic institutions, because they include a system of values, such as moderation, trust, tolerance, participation, and acceptance of political and intellectual pluralism (Dawn, 2000).

It should be noted that educational and media institutions can be considered as tools for spreading a democratic political culture among the various segments of society. This requires continuing efforts to reform media and educational policies, thus enhancing their roles in awareness raising, counseling and combating the negative aspects of society, to be an important input to the comprehensive reform process and the dissemination of the values of democracy and progress (Dawn, 2000).

(5) Strengthening the importance of the institutions of civil society and their independence from the state, through the amendment of legal frameworks restricting these institutions to ensure their movement and freedom. These institutions must develop their institutional frameworks, commitment to the implementation of democracy at the internal level, and develop their relationship with the community in order to strengthen their social norms to be the bell that beats to inform the political authority about the disadvantages and mistakes in society. Or that the human being is exposed to in his daily life, because these institutions are a link between society and political power (Kamal, 2017).

(6) The necessity of taking over the authority by competent and experienced persons (technocratic government) that is not subject to abhorrent sectarian quotas or narrow partisan loyalties.

Such competencies should employ their expertise, skills, and knowledge in the interests of the countries, which are linked to their national and security interests, discipline in responsibilities, and prudence in choices. Then, the reform will turn into characteristics of regularity in relations, discipline in responsibilities, and rationalization of options (Technocracy and the Technocratic Government, 2016).

For example, the main reason for the power of the United States of America as a superpower is its political system based on the separation of the three powers, the adoption of the Constitution in the application of laws, and the mutual respect of the three authorities for each other.

(7) The need to achieve transparency in the work of the administration and the application of accountability on the results of its activities and actions, that allowing citizens the right to participate in decisions and policy development.

In this way, we put an end to corruption in all its forms and wrong practices to achieve administrative quality, contributing to the maintenance of public funds, rationalizing the process of allocating resources, absorbing differences in all fields, and restoring citizens.

This can only be achieved within the framework of the rule of law, which upholds justice and guarantees rights and freedoms. Taking such serious steps supports the approach of political reform and democratization and strengthens the legitimacy of the existing regime (Kurdi, 2011). 
(8) Treating the economic and social problems through improving the performance of the administrative apparatus suffered by the state. This contributes to creating an enabling environment for the continuation of the process of political reform.

For example, the treatment of economic problems by finding important alternatives to oil, such as the revival of idle factories, where there are more than four thousand factory idle, as well as the expansion of agricultural production so that there is a capacity to suffice the domestic consumption, with export capacity and encourage manufacturing agriculture. In textile or food industries, this will provide job opportunities for the labor force and reduce the unemployment among the youth, and make them away from the influence of the hostile parties to Iraq (Al-Dabbagh, 2007).

(9) The need to strengthen the idea of army independence and other security services from the ruling political parties, as a guarantor of all parties.

The role of the army is to protect the homeland to guarantee the rights and interests of the people on a hand. On the other hand, the independence, integrity, and efficiency of these services reduce the chances of establishing authoritarian dictatorships (Izzat, 2017).

(10) The independence of the Iraqi judiciary is necessary, as it forms the basis on which the process of building the state, away from the quotas and politicization of party and sectarian, and its independence from the legislative and executive powers.

All pressures are removal because the reform of the judiciary is the first brick in the reform of the Iraqi state in all its institutions, and then, can be processed other files in a gradual manner. The goal is to achieve justice, which cannot be achieved with the absence of one of its basic components and protect it from any interference or impact (Issawi, 2015).

(11) Formation of an independent national body called "national commission for reform monitoring and evaluation” by all segments of the Iraqi people (i.e., parties, unions, independents, associations, and other powers). It is supported by the parliament and facilitated by the government to carry out their tasks issuing a monthly report on "The report of indicators of achievement in reform" and its recommendations are binding on the government.

In conclusion, we say that these elements, in the case of activation, may be heavy of the reform ship to the beach safety and transition in the field of politics from sectarian to national, in society from conflict to consensus, in religion from collisions to compassion, and in education from opacity to quality.

\section{Conclusions}

Through this research, we can conclude that the reform and the demand for it are not a new matter, but it is a long-standing one. The efforts to reform by the forces of the societies, especially the Arab ones, have not stopped but they have been aborted or contained, because of the culture of tyranny and subjection, and the accompanying instability in the societies of those countries, and this is what colonialism wants.

As it is known, Iraqi society is a diverse society in terms of social, intellectual, religious, national, and ethnic. Recognition of these variations is a qualitative step in the political and national reform project. It is also a basic floor for sustained national dialogue to treat the country's crises at all levels.

Political reform is the necessary step required to end all manifestations of rejection and the fight against diversity of national space. 
First and foremost is the reform of the human self, which is the basic block in the community building, and then, to create the appropriate environment, to build the state properly, and to raise the performance of government and parliament in Iraq to the level of good governance based on the principle of equality.

To give equal opportunities to all to advance society towards a better tomorrow, all this depends on the cooperation and participation of national political forces without exception, as well as the participation and cooperation of the central government with lcoal governments, and even civil society organizations. Then, the success and rise of government, and parliamentary performance will be a success for all and failure will be a failure for all.

Here lies the importance of political reform in that it is not only a popular demand but a necessity for political and social stability.

Engaging in the political reform project and dealing with its issues with a new mentality is moving towards eliminating all tensions that harm the security and unity of the country.

Then, the regime will be able to face the challenges of the interior and external pressures.

\section{References}

Al-Asadi, F. H., Sakhi, G. M., Lafta, S. A., \& Taamas, Y. Y. (2013). Socialism: A systematic book for the fifth primary grade (1st ed.). Baghdad: The Modern Waqf Press.

Alay, S. J., Yasin, \& Al-Ithawi, M. H. (2014). Political reform in the Arab countries: A study of projects abroad and inside (1st ed.). Amman: Dar Amjad for Publishing and Distribution.

Al-Dabbagh, O. B. (2007). Unemployment and inflation: Theoretical hypotheses and methods of economic policy (1st ed.). Amman: Al Ahlia for Publishing and Distribution.

Al-Hassani, J. T. (1993). Arab-Islamic political thought: A study in the most emotional trends of thought. Baghdad: Dar al-Kutub for Printing and Publishing.

Al-Jaadi, T. (2011). Obstacles to political reform. Retrieved from http://www.yemen-press.com

Al-Kayali, A. (2009). Encyclopedia of politics (Part 1, 5th ed.). Beirut: the Arab Foundation for Studies and Publishing.

Al-Lozi, M. (2002). Administrative development (2nd ed.). Amman: Dar Wael.

Al-Said, M. M. (2011). The concept of political reform: Civilized dialogue. Retrieved from http://www.ahwer.org/debat/ show. art.asp?aid=28459

Al-Taan, A. H. (1992). History of modern political thought. Baghdad: Dar al-Hikma for Printing and Publishing.

Al-Zubaidi, W. (2011). Iraq: The deadlock and salvation. The Future of the Arab Magazine. Beirut: Center for Arab Unity Studies.

Atwan, K. A. (2011). The political system in Iraq between reform and legitimacy: An analytical view in the light of the demonstration approach in 2011. In A series of studies and research papers. Doha, Qatar: Arab Center for Research and Policy Studies.

Baalbaki, M. (1977). Dictionary of resources (1st ed.). Beirut: Dar al-Ilm Lilmalayeen.

Badawi, A. R. (1942). Plato. Cairo: The Egyptian Renaissance Library.

Batato, H. (2005). Social classes and revolutionary movements in the Ottoman era until the establishment of the republic (1st ed., A. Al-Razzaz, Trans.). Iran: Frasad Publications.

Dawn, D. (2000). Education and the Arab world: Challenges of the third millennium (1st ed.). Abu Dhabi: Emirates Center for Strategic Studies and Research.

Faris, F. K. (2017). On the future of Iraq: Conclusions and recommendations. Retrieved from http://www.iraqicp.com

Farouk, M., \& Slogelt, P. (2003). From revolution to dictatorship: Iraq since 1958. (M. Nebrasi, Trans.). Beirut: Dar al-Jamal.

Hafez, A. A. J. (2001). The democratic transition in Iraq: Reality and the future. Beirut: Madar Mortada Foundation.

Hamid, A. A. A. (2014). Towards a national approach to economic reform in Iraq. Retrieved from http://www.uobabylon.edu.iq

Issawi, M. M. (2015). Reform of the Iraqi judiciary: A political vision. Retrieved from http://www.authorsarticle sarabicm.annabaa.org

Izzat, A. I. (2017). Reform in Iraq. Retrieved from http://www.rudow.net 
Kamal, A. (2017). The role of civil society institutions in combating corruption. Al-Sabah Al-Jadeed newspaper, July 28.

Kurdi, A. E. S. (2011). Managing transparency: The road to development and administrative reform. Retrieved from http://kenana/users/ahmed kordy/posts/280892

Mahfouz, M. (2005). Freedom and reform in the Arab world (1st ed.). Beirut: Arab Science House.

Powell, J. (1985). Western political thought. (M. R. Khamis, Trans.). Cairo: Egyptian Book Association.

Saad, I. A. (1983). Society and politics: Applied theory studies (1st ed.). Alexandria: Dar Al Maarifa al-Jameeya.

Technocracy and the Technocratic Government. (2016). A brief study. Retrieved from http://www.bayancnter.org

Thomas, H. (1964). Flags of the philosophers: How to understand them. (M. Amin, Trans.). Cairo: Dar al-Nahda al-Arabiya. 